\title{
Editorial
}

\section{El "Libro Blanco" de la SECOM}

\author{
The SECOM "White Paper"
}

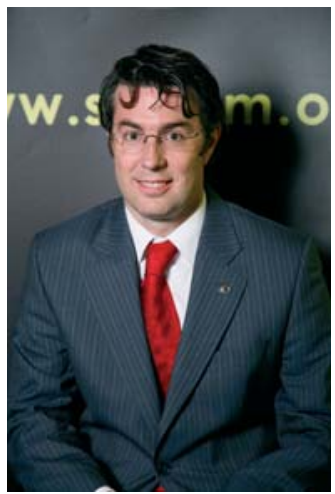

\author{
Rafael Martín-Granizo López \\ Director
}

No cabe duda que los "libros blancos" están de moda. Más cuando un candidato a la Presidencia del Gobierno de España lo mostró recientemente ante las cámaras de TV en uno de los famosos y mediáticos debates en las pasadas Elecciones Generales. Curiosamente, aquel "libro blanco" estaba... en blanco, no sé si porque no sabía con qué llenarlo o si quería que lo rellenásemos entre todos.

A pesar de esta reciente moda, la Sociedad Española de Cirugía Oral y Maxilofacial (SECOM) lleva ya desde el año 2002 detrás de hacer un libro blanco sobre nuestra especialidad. Y el libro, no ha visto la luz, no por falta de ganas e interés, sino por el elevado coste que a la Sociedad le suponía. Afortunadamente, el nuevo cambio en el sistema de gerencia y funcionamiento de la SECOM ha propiciado que, a día de hoy, la Junta Directiva, liderada por su Presidente, Santiago Llorente, haya puesto en marcha este importante proyecto.

Huelga decir la importancia que este proyecto tiene para nuestra especialidad. Porque, el libro blanco lo realizará la Sociedad, pero sobre toda la especialidad de cirugía oral y maxilofacial. Tenemos la gran fortuna que la gran mayoría de titulados en cirugía oral y maxilofacial pertenecen a la SECOM, hecho que no ocurre en otras especialidades médicas ni en la odontología. No exageramos si decimos que es uno de los más importantes proyectos que nuestra Sociedad acometerá en sus 30 años de vida.

Los "libros blancos" se llaman así porque en ellos se puede poner "lo que cada uno quiera". El Diccionario de la Lengua Española lo define como "el que contiene un informe completo o una serie de propuestas sobre el estado de alguna cuestión o materia". Es decir, son instrumentos importantes para reflejar una situación determinada sobre un organismo y establecer unas recomendaciones de actuación basada en ella. Por eso, en nuestro caso el objetivo sería ofrecer una visión actual del estado de nuestra especialidad así como elaborar un plan estratégico de la misma para el futuro. Desarrollaremos áreas tan relevantes como la especialidad en el Sector Público, en la Sanidad Privada, en la Docencia y Formación, así como en la Investigación y Publicaciones Científicas, sin olvidar nuestras relaciones internacionales y el marco jurídico en el que nos movemos. Para ello, la Junta Directiva ha aprobado un Comité de Dirección muy completo y capaz que desarrollará las diferentes partes
"White Papers" are certainly fashionable now. Just recently, a Spanish presidential candidate held up a white paper before television cameras in one of the most famous and media-intensive debates in the latest general elections. Interestingly, the "white paper" was blank, I don't know whether it was because the candidate didn't know what to fill it with or because he wanted to fill it with his constituents.

Despite this recent fashion, the Spanish Society of Oral and Maxillofacial Surgery (SECOM, Spanish initials) has worked since 2002 on a white paper targeting our specialty. The book has yet to see the light of day, not for lack of enthusiasm and interest, but because it is so expensive for our Society. Fortunately, recent changes in SECOM management and operation have allowed the Executive Board, led by its President, Santiago Llorente, to get this important project going.

What this project means to our specialty cannot be underestimated. The SECOM white paper will deal with all the specialty of oral and maxillofacial surgery. We are fortunate that the majority of the people with degrees in oral and maxillofacial surgery belong to the SECOM. This is not the case of other medical specialties or odontology. We are not exaggerating when we say that it is one of the most important projects that our Society has embarked upon in our 30-year history.

"White papers" receive this name because they are blank pages open to receiving "anything we want." The Diccionario de la Lengua Española (Dictionary of the Spanish Language) defines a white paper as "a paper containing a complete report or a series of proposals on the state of a certain question or matter." This means that they are important instruments that reflect the situation of a body and establish recommendations for action. For that reason, our aim is to offer a current vision of the state of our specialty and to prepare a strategic plan for the specialty in the future. We will develop areas as relevant as the role of the specialty in the public and private health sectors, teaching and training, and scientific research and publications, without overlooking international relations and the legal framework in which the pro- 
del mismo, coordinados por mí. También contamos con la ayuda y asesoramiento de una empresa líder con suficiente experiencia en la elaboración de estos trabajos, que empleará principalmente una metodología mediante encuestas y estadísticas, analizando no solo variables cuantitativas sino también cualitativas y de satisfacción.

Pero no lo olvidemos. El Libro Blanco de la SECOM, será el libro de todos, elaborado por todos nosotros como especialistas y miembros de la SECOM, por lo que necesitamos la imprescindible colaboración de aquellos a los que se les requiera. No tengáis duda, que será nuestra más importante arma para luchar por el futuro científico y laboral de nuestra especialidad. Gracias de antemano por vuestra segura colaboración. fession operates. The Executive Board has approved a very well represented and capable Steering Committee to develop different parts of the strategy. I will be coordinating this committee. We will be advised and assisted by a leading company that is experienced in preparing this work. This company will use a methodology based mainly on surveys and statistics, in which they will analyze not only quantitative but qualitative variables and satisfaction measures.

Let us not forget, however, that the SECOM White Book will be our book, prepared by all of us as specialists and members of SECOM. This is why we are counting on all of you for the essential collaboration. Have no doubt that it will be our most important weapon in our efforts to ensure the scientific and occupational future of our specialty. I would like to thank all of you in advance for your colaboration. 